\title{
Disease Response Reason Not Done
}

National Cancer Institute

\section{Source}

National Cancer Institute. Disease Response Reason Not Done. NCI Thesaurus. Code C117398.

The rationale why a disease response assessment was not performed. 